\title{
Accelerated Fractionation Plus Chemotherapy Versus Conventionally Fractionated Radiochemotherapy for Unresectable Head-and-Neck Cancer
}

\author{
DIRK RADES ${ }^{1}$, CARLOS A. NARVAEZ ${ }^{1}$, STEFAN JANSSEN ${ }^{1,2}$, URSULA SCHRÖDER $^{3}$, \\ KARL L. BRUCHHAGE ${ }^{3}$, SAMER G. HAKIM $^{4}$, TOBIAS BARTSCHT ${ }^{5}$ and STEVEN E. SCHILD 6 \\ ${ }^{1}$ Department of Radiation Oncology, University of Lübeck, Lübeck, Germany; \\ ${ }^{2}$ Private Practice of Radiation Oncology, Hannover, Germany; \\ ${ }^{3}$ Department of Oto-Rhino-Laryngology and Head and Neck Surgery, University of Lübeck, Lübeck, Germany; \\ ${ }^{4}$ Department of Oral and Maxillofacial Surgery, University of Lübeck, Lübeck, Germany; \\ ${ }^{5}$ Department of Hemotology and Oncology, University of Lübeck, Lübeck, Germany; \\ ${ }^{6}$ Department of Radiation Oncology, Mayo Clinic, Scottsdale, AZ, U.S.A.
}

\begin{abstract}
Background/Aim: Prognosis of patients with unresectable squamous cell carcinomas of the head and neck requires improvement. This retrospective study compared accelerated radiotherapy plus chemotherapy to conventional radiochemotherapy. Patients and Methods: Patients received definitive treatment with accelerated radiotherapy plus chemotherapy (group A, n=10) or conventional cisplatin-based radiochemotherapy (group $B$, $n=85$ ). Groups were matched for several patient and tumor characteristics and compared for locoregional control (LRC), overall survival (OS) and toxicities. Additionally, accelerated radiotherapy plus chemotherapy and chemotherapy regimens in group B were compared for $L R C$ and OS. Results: Treatment type had no significant impact on LRC ( $p=0.98)$ and $O S(p=0.57)$. In group A, toxicities occurred more often, including grade $\geq 3$ mucositis $(p=0.041)$, grade $\geq 2$ lymphedema $(p=0.007)$ and grade $\geq 3$ leucopenia $(p=0.007)$. Best 2-year LRC $(p=0.39)$ and $O S$ $(p=0.015)$ was achieved with $20 \mathrm{mg} / \mathrm{m}^{2}$ cisplatin days $1-5$ every 4 weeks; accelerated radiochemotherapy resulted in second-worst outcomes. Conclusion: Given the limitations of this study, accelerated radiotherapy plus chemotherapy
\end{abstract}

This article is freely accessible online.

Correspondence to: Professor Dirk Rades, MD, Department of Radiation Oncology, University of Lübeck, Ratzeburger Allee 160, 23538 Lübeck, Germany. Tel: +49 45150045400, Fax: +49 45150045404,e-mail: rades.dirk@gmx.net

Key Words: Unresectable HNSCC, accelerated fractionation plus chemotherapy, conventionally fractionated radiochemotherapy, treatment outcomes, toxicities. provided no significant benefit but increased toxicity compared to conventional radiochemotherapy.

In both developing and developed countries, squamous cell carcinomas of the head and neck (HNSCC) are common malignant tumors (1-3). For most resectable tumors, the standard treatment includes surgery followed by adjuvant radiotherapy or, if risk factors exist such as incomplete resection and extracapsular spread of lymph node metastases, by radiochemotherapy (4).

Unfortunately, many patients present with locally advanced tumors that are unresectable and require definitive radiochemotherapy $(2,3)$. According to randomized trials and meta-analyses, outcomes of definitive radiotherapy are considerably improved with the addition of concurrent (mainly cisplatin-based) chemotherapy (5-8). However, since the addition of chemotherapy results in increased acute toxicities, some patients are not suitable for combined treatment and receive radiotherapy alone (9-11). According to a metaanalysis, unconventionally fractionated radiotherapy with reduced overall treatment times resulted in improved locoregional control (LRC) and overall survival (OS) compared to conventionally fractionated radiotherapy $(2.0 \mathrm{~Gy}$ per fraction on 5 days per week) (12). Types of unconventionally fractionated radiotherapy include hyperfractionated accelerated radiotherapy (HA-RT) and accelerated fractionation with concomitant boost (AF-CB) $(12,13)$.

In order to further improve the outcomes of patients with unresectable HNSCC, several studies investigated the option of combining accelerated radiotherapy and chemotherapy. In some studies, feasibility of HA-RT or AF-CB plus chemotherapy was shown (14-17). Moreover, a few randomized trials demonstrated that the addition of chemotherapy to accelerated radiotherapy 
resulted in better outcomes than accelerated radiotherapy alone (18-20). Another important question is whether accelerated radiotherapy plus chemotherapy is superior to standard conventional radiochemotherapy. According to two randomized trials, accelerated radiotherapy plus chemotherapy did not result in improved outcomes $(21,22)$. One trial compared AF-CB (70 Gy in 40 fractions over 6 weeks) plus two 5-day courses of carboplatin/5-fluorouracil (5-FU) to conventionally fractionated radiotherapy (70 Gy in 35 fractions over 7 weeks) plus three 4day courses of carboplatin/5-FU (21). The other trial compared AF-CB (72 Gy in 42 fractions over 6 weeks) plus two courses of $100 \mathrm{mg} / \mathrm{m}^{2}$ of cisplatin on day 1 to conventionally fractionated radiotherapy (70 Gy in 35 fractions over 7 weeks) plus three courses of $100 \mathrm{mg} / \mathrm{m}^{2}$ of cisplatin on day 1 (22). Several other concepts of AF-CB or HA-RT plus chemotherapy exist that have not yet been compared to conventional radiochemotherapy. In this study, patients receiving accelerated radiotherapy plus chemotherapy within previous trials were matched to patients receiving conventionally fractionated cisplatin-based chemotherapy and compared for treatment outcomes and toxicities.

\section{Patients and Methods}

The data of 95 patients with histologically proven unresectable nonmetastatic stage IV SCCHN were retrospective analyzed. Staging was performed according to the $7^{\text {th }}$ edition of the American Joint Committee on Cancer manual, since for classification according to the eighth edition, the human papilloma virus status is mandatory for tumors of the oropharynx but was not available for the majority of patients of the present study $(23,24)$. The study received approval from the local Ethics Committee (University of Lübeck, reference 20-454).

Ten patients received definitive treatment with accelerated fractionation plus chemotherapy within clinical trials between 2010 and 2014 (group A). They were matched and compared to 85 patients from an anonymized database treated with conventionally fractionated radiochemotherapy between 2000 and 2014 (group B).

Group A. In group A, three patients received HA-RT that started with 30 Gy (2.0 Gy per fraction on 5 days per week) over 3 weeks, followed by a hyperfractionated-accelerated part with two daily fractions of $1.4 \mathrm{~Gy}$ (inter-fraction interval $\geq 6 \mathrm{~h}$ ) over another 3 weeks, resulting in a cumulative dose of 70.6 Gy in 44 fractions over 6 weeks $(17,25)$. Radiotherapy was combined with concurrent cisplatin $\left(40 \mathrm{mg} / \mathrm{m}^{2}\right.$ weekly) and cetuximab $\left(400 \mathrm{mg} / \mathrm{m}^{2}\right.$ loading dose 1 week prior to radiotherapy, followed by $250 \mathrm{mg} / \mathrm{m}^{2}$ weekly).

Four patients were assigned to induction chemotherapy with three courses of docetaxel $\left(75 \mathrm{mg} / \mathrm{m}^{2}\right)$ and cisplatin $\left(75 \mathrm{mg} / \mathrm{m}^{2}\right)$ with $(\mathrm{n}=3)$ or without $\left(\mathrm{n}=1\right.$ ) cetuximab (loading dose of $400 \mathrm{mg} / \mathrm{m}^{2}$ followed by $250 \mathrm{mg} / \mathrm{m}^{2}$ for a total of 16 weeks during induction and radiotherapy periods) (26). In these four patients, radiotherapy was performed as AF-CB. Radiation of 30 Gy (2.0 Gy per fraction on 5 days per week) over 3 weeks was followed by additional 21.6 Gy (1.8 Gy per fraction) to the same areas over 2.5 weeks (12 treatment days) plus two consecutive boost doses (1.5 Gy per fraction) given the same days (i.e. $6+6$ treatment days) after an interval of $\geq 6 \mathrm{~h}$, resulting in a cumulative dose of $69.6 \mathrm{~Gy}$ in 39 fractions over 5.5 weeks.
Three patients received HA-RT starting with 30 Gy (2.0 Gy per fraction on 5 days per week) over 3 weeks, followed by hyperfractionated-accelerated radiotherapy including two daily fractions of $1.4 \mathrm{~Gy}$ (interval $\geq 6 \mathrm{~h}$ ) over another 2.5 weeks, resulting in a cumulative dose of $63.6 \mathrm{~Gy}$ in 39 fractions over 5.5 weeks (27). Radiotherapy was combined with concurrent cisplatin $\left(20 \mathrm{mg} / \mathrm{m}^{2}\right.$ on days 1-4 and 29-32) and paclitaxel $\left(20 \mathrm{mg} / \mathrm{m}^{2}\right.$ on days $2,5,8,11$ and $25,30,33,36$ ).

Group B. In group B, 85 patients were assigned to conventionally fractionated radiotherapy with concurrent cisplatin-based chemotherapy. Radiotherapy started with 50 Gy (2.0 Gy per fraction on 5 consecutive days per week) over 5 weeks to the primary tumor and regional lymph nodes, followed by boost doses to primary tumor and high/intermediate-risk lymph node areas, resulting in a cumulative dose of $70 \mathrm{~Gy}$ in 35 fractions over 7 weeks. Concurrent chemotherapy regimens included $30 \mathrm{mg} / \mathrm{m}^{2}$ of cisplatin on day 1 every week $(\mathrm{n}=21), 100 \mathrm{mg} / \mathrm{m}^{2}$ of cisplatin on day 1 every 3 weeks $(\mathrm{n}=17), 20 \mathrm{mg} / \mathrm{m}^{2}$ of cisplatin on days $1-5$ every 4 weeks $(n=24)$ and $20 \mathrm{mg} / \mathrm{m}^{2}$ of cisplatin on days $1-5$ plus 600 or $1000 \mathrm{mg} / \mathrm{m}^{2}$ of 5 -FU on days $1-5$ every 4 weeks $(n=23)$.

Endpoints and statistical considerations. Groups A and B were matched for tumor site (oropharynx versus hypopharynx versus larynx), gender, age at radiotherapy ( $\leq 55$ versus $>55$ years), primary tumor category (T2-3 versus $\mathrm{T} 4)$, lymph node category (N0-2a versus $\mathrm{N} 2 \mathrm{~b}-2 \mathrm{c})$ and histological grade (G1-2 versus $\mathrm{G} 3$ ). Matching for Karnofsky performance score was not performed, since all patients had a score of 80-100. Distributions of the patient characteristics between groups A and B were compared using Fisher's exact test (Table I).

The groups were compared for the endpoints LRC and OS, which were referenced from the last day of radiotherapy. For the corresponding univariate analyses, the Kaplan-Meier method and the log-rank test were used. Characteristics that achieved significance $(p<0.05)$ on univariate analyses were included in a multivariate analysis (Cox regression analysis).

Groups A and B were also compared for radiation-related toxicities (acute: oral mucositis and dermatitis; late: cervical lymph edema and xerostomia), chemotherapy-related toxicities (leucopenia, thrombopenia, anemia and reduced renal function), toxicity-related interruptions of radiotherapy longer than 1 week and toxicity-related impossibility to administer the complete chemotherapy as planned (Fisher's exact test). Again, $p$-values less than 0.05 indicated significance. In addition, accelerated fractionation plus chemotherapy (group A) and the different chemotherapy regimens used in group B were compared for LRC and OS.

\section{Results}

Median follow-up periods were 19 months (range $=0-112$ months) for the entire cohort, 16.5 months (range=0-112 months) for group A and 19 months (range=0-70 months) for group B. On univariate analysis, better LRC was significantly associated with favorable tumor sites (oropharynx or larynx, $p=0.008$ ) and female gender $(p=0.016)$ (Table II). For the type of treatment, no significant association was found with LRC $(p=0.98)$. In the Cox regression analysis, female gender maintained significance 
Table I. Characteristics of patients treated with accelerated fractionation plus chemotherapy (group A) and conventionally fractionated radiochemotherapy (group B). p-Values of the comparisons between both groups were obtained from Fisher's exact test.

\begin{tabular}{|c|c|c|c|}
\hline Characteristic & $\begin{array}{c}\text { Group A } \\
\mathrm{N}(\%)\end{array}$ & $\begin{array}{c}\text { Group B } \\
\mathrm{N}(\%)\end{array}$ & $p$-Value \\
\hline \multicolumn{4}{|l|}{ Tumor site } \\
\hline Oropharynx & $5(50)$ & $46(54)$ & \multirow[t]{3}{*}{$>0.99 *$} \\
\hline Hypopharynx & $2(20)$ & $18(21)$ & \\
\hline Larynx & $3(30)$ & $21(25)$ & \\
\hline \multicolumn{4}{|l|}{ Gender } \\
\hline Female & $3(30)$ & $14(19.4)$ & \multirow[t]{2}{*}{0.72} \\
\hline Male & $7(70)$ & $58(80.6)$ & \\
\hline \multicolumn{4}{|c|}{ Age at radiotherapy } \\
\hline$\leq 55$ Years & $2(20)$ & $20(27.8)$ & \multirow[t]{2}{*}{0.72} \\
\hline$>55$ Years & $8(80)$ & $52(72.2)$ & \\
\hline \multicolumn{4}{|l|}{ T-Category } \\
\hline $2-3$ & $3(30)$ & $22(30.6)$ & \multirow[t]{2}{*}{$>0.99$} \\
\hline 4 & $7(70)$ & $50(69.4)$ & \\
\hline \multicolumn{4}{|l|}{ N-Category } \\
\hline $0-2 \mathrm{a}$ & $4(40)$ & $18(25.0)$ & \multirow[t]{2}{*}{$>0.99$} \\
\hline $2 b-2 c$ & $6(60)$ & $54(75.0)$ & \\
\hline \multicolumn{4}{|c|}{ Histological grade } \\
\hline $1-2$ & $6(60)$ & $53(73.6)$ & \multirow[t]{2}{*}{$>0.99$} \\
\hline 3 & $4(40)$ & $19(26.4)$ & \\
\hline
\end{tabular}

*For calculation of the $p$-value, hypopharynx and larynx were combined.

[risk ratio $(\mathrm{RR})=3.42,95 \%$ confidence interval $(\mathrm{CI})=1.32$ $11.64, p=0.023)]$, whereas favorable tumor sites were not significant $(\mathrm{RR}=1.06,95 \% \mathrm{CI}=0.71-1.66, p=0.77)$.

On univariate analysis, improved OS was significantly associated with favorable tumor sites $(p<0.001)$ and female gender $(p=0.012)$ (Table III). No significant difference regarding OS was found between treatment groups A and B $(p=0.57)$; however, OS appeared numerically better in group B (65\% versus $40 \%$ at 2 years). In the Cox regression analysis, female gender was significant $(\mathrm{RR}=2.68,95 \%$ $\mathrm{CI}=1.27-6.59, p=0.008)$, whereas favorable tumor sites were not significant $(\mathrm{RR}=1.09,95 \% \mathrm{CI}=0.77-1.59, p=0.63)$.

The comparisons of groups $\mathrm{A}$ and $\mathrm{B}$ with respect to treatment-related toxicities showed that the treatment in group A (accelerated fractionation plus chemotherapy) was associated with significantly higher rates of grade $\geq 3$ oral mucositis $(p=0.041)$, grade $\geq 2$ cervical lymph edema $(p=0.007)$, grade $\geq 3$ leucopenia $(p=0.007)$, grade $\geq 2$ thrombopenia $(p=0.002)$, grade $\geq 3$ thrombopenia $(p=0.029)$ and grade $\geq 2$ anemia $(p=0.013)$. Moreover, trends were found for increased toxicity in group A with respect to grade $\geq 2$ radiation dermatitis $(p=0.20)$, grade $\geq 3$ cervical lymphedema $(p=0.14)$ and grade $\geq 1$ reduced renal function
Table II. Comparison of locoregional control in patients according to treatment [(accelerated fractionation plus chemotherapy (group A) versus conventionally fractionated radiochemotherapy (group B)] and patient characteristics (univariate analyses). p-Values were obtained from log-rank test.

\begin{tabular}{lccc}
\hline Characteristic & 1 Year $(\%)$ & 2 Years $(\%)$ & $p$-Value \\
\hline $\begin{array}{l}\text { Treatment group } \\
\text { Group A }\end{array}$ & 89 & 53 & 0.98 \\
$\quad$ Group B & 74 & 69 & \\
Tumor site & & & \\
$\quad$ Oropharynx & 80 & 72 & $\mathbf{0 . 0 0 8}$ \\
Hypopharynx & 47 & 40 & \\
Larynx & 87 & 80 & \\
Gender & & & \\
Female & 100 & 89 & $\mathbf{0 . 0 1 6}$ \\
$\quad$ Male & 66 & 59 & \\
Age at radiotherapy & & & \\
$\quad \leq 55$ Years & 64 & 64 & 0.24 \\
$\quad>55$ Years & 80 & 69 & \\
T-Category & & & \\
2-3 & 80 & 75 & 0.69 \\
4 & 74 & 65 & \\
N-Category & & & \\
0-2a & 82 & 68 & 0.49 \\
2b-2c & 70 & 67 & \\
Histological grade & & & \\
1-2 & 74 & 64 & 0.58 \\
3 & 78 & 74 & \\
\hline
\end{tabular}

Significant $p$-values are given in bold.

$(p=0.12)$. The rates of all investigated toxicities are summarized in Table IV. In group A, all patients received the planned total radiation doses. In two patients $(2 \%)$ of group B, radiotherapy was discontinued prior to $70 \mathrm{~Gy}$ because of treatment-related toxicity, and six patients (7\%) received less than 70 Gy due to other reasons. Data regarding interruptions of radiotherapy longer than 1 week and completion of planned chemotherapy were available for all patients of group A and 64 patients of group B. Interruptions of radiotherapy longer than 1 week became necessary for one patient (10\%) of group A and 10 patients (16\%) of group B $(p>0.99)$. Chemotherapy was not given as planned to four patients (40\%) of group A and 17 patients (27\%) of group B $(p=0.46)$.

When comparing accelerated fractionation plus chemotherapy (group A) and the different chemotherapy regimens used in group $\mathrm{B}$, the best 2 -year LRC rates were achieved with $20 \mathrm{mg} / \mathrm{m}^{2}$ of cisplatin on days $1-5$ every 4 weeks followed by $100 \mathrm{mg} / \mathrm{m}^{2}$ of cisplatin on day 1 every 3 weeks and $20 \mathrm{mg} / \mathrm{m}^{2}$ of cisplatin on days $1-5$ plus $5-\mathrm{FU}$ every 4 weeks. OS rates at 2 years were most favorable with $20 \mathrm{mg} / \mathrm{m}^{2}$ of cisplatin on days $1-5$ every 4 weeks followed by $100 \mathrm{mg} / \mathrm{m}^{2}$ of cisplatin on day 1 every 3 weeks. The 
Table III. Comparison of overall survival in patients according to treatment [(accelerated fractionation plus chemotherapy (group A) versus conventionally fractionated radiochemotherapy (group B)] and patient characteristics (univariate analyses). p-Values were obtained from log-rank test.

\begin{tabular}{lccc}
\hline Characteristic & 1 Year $(\%)$ & 2 Years $(\%)$ & $p$-Value \\
\hline $\begin{array}{l}\text { Treatment group } \\
\text { Group A }\end{array}$ & 50 & 40 & 0.57 \\
$\quad$ Group B & 80 & 65 & \\
Tumor site & & & \\
$\quad$ Oropharynx & 80 & 70 & $\mathbf{< 0 . 0 0 1}$ \\
$\quad$ Hypopharynx & 55 & 27 & \\
$\quad$ Larynx & 88 & 75 & \\
Gender & & & \\
$\quad$ Female & 96 & 85 & $\mathbf{0 . 0 1 2}$ \\
Male & 70 & 54 & \\
Age at radiotherapy & & & \\
$\quad$ 55 Years & 70 & 56 & 0.30 \\
$\quad$ 55 Years & 79 & 64 & \\
T-Category & & & \\
2-3 & 80 & 71 & 0.33 \\
4 & 75 & 58 & \\
N-Category & & & \\
0-2a & 79 & 64 & 0.84 \\
2b-2c & 75 & 60 & \\
Histological grade & & & \\
1-2 & 80 & 62 & 0.93 \\
3 & 72 & 62 & \\
\hline
\end{tabular}

Significant $p$-values are given in bold.
Table IV. Comparison of grade $\geq 2$ toxicities in patients treated with accelerated fractionation plus chemotherapy (group A) and conventionally fractionated radiochemotherapy (group B). p-Values were obtained from Fisher's exact test.

\begin{tabular}{|c|c|c|c|}
\hline Toxicity & $\begin{array}{c}\text { Group A } \\
\mathrm{N}(\%)\end{array}$ & $\begin{array}{c}\text { Group B } \\
\mathrm{N}(\%)\end{array}$ & $p$-Value \\
\hline \multicolumn{4}{|c|}{ Oral mucositis } \\
\hline$\geq 2$ & $10(100)$ & $79(93)$ & $>0.99$ \\
\hline$\geq 3$ & $9(90)$ & $46(54)$ & 0.041 \\
\hline \multicolumn{4}{|c|}{ Radiation dermatitis } \\
\hline$\geq 2$ & $10(100)$ & $67(79)$ & 0.20 \\
\hline$\geq 3$ & $3(30)$ & $22(26)$ & 0.72 \\
\hline \multicolumn{4}{|c|}{ Cervical lymph edema* } \\
\hline$\geq 2$ & $7(70)$ & $15(24)$ & 0.007 \\
\hline$\geq 3$ & $1(10)$ & $0(0)$ & 0.14 \\
\hline \multicolumn{4}{|c|}{ Xerostomia* } \\
\hline$\geq 2$ & $6(60)$ & $49(64)$ & $>0.99$ \\
\hline$\geq 3$ & $0(0)$ & $3(4)$ & $>0.99$ \\
\hline \multicolumn{4}{|c|}{ Leucopenia } \\
\hline$\geq 2$ & $6(60)$ & $41(48)$ & 0.52 \\
\hline$\geq 3$ & $6(60)$ & $15(18)$ & 0.007 \\
\hline \multicolumn{4}{|c|}{ Thrombopenia } \\
\hline$\geq 2$ & $4(40)$ & $3(4)$ & 0.002 \\
\hline$\geq 3$ & $2(20)$ & $1(1)$ & 0.029 \\
\hline \multicolumn{4}{|l|}{ Anemia } \\
\hline$\geq 2$ & $8(80)$ & $30(35)$ & 0.013 \\
\hline$\geq 3$ & $0(0)$ & $8(9)$ & 0.59 \\
\hline \multicolumn{4}{|c|}{ Reduced renal function* } \\
\hline$\geq 1$ & $5(50)$ & $15(23)$ & 0.12 \\
\hline$\geq 2$ & $2(20)$ & $8(13)$ & 0.62 \\
\hline
\end{tabular}

*In group B, data regarding cervical lymph edema were available for 62 patients, xerostomia for 77 patients, and reduced renal function for 64 patients. Significant $p$-values are given in bold.

\section{Discussion}

Conventional cisplatin-based radiochemotherapy is considered the standard treatment for unresectable HNSCC $(7,8)$. However, a considerable number of patients cannot tolerate the addition of chemotherapy to radiotherapy, which significantly increases toxicity $(9,10,28)$. This also applies to other systemic therapies $(20,29,30)$. In patients unable to receive radiochemotherapy, improved outcomes were shown for unconventional fractionation such as HA-RT and $\mathrm{AF}-\mathrm{CB}(12,13,31)$. When considering the superior results of unconventional compared to conventional fractionation, the idea was created to combine HA-RT or AF-CB with systemic agents.

In 2005, a feasibility study was reported that included 84 patients with locally advanced HNSCC (14). Seventy-six patients were evaluable and 65 patients treated per protocol receiving AF-CB with 72 Gy in 42 fractions over 6 weeks $(30 \times 1.8 \mathrm{~Gy} /$ day plus a concomitant boost of $1.5 \mathrm{~Gy}$ given the same day for the last 12 days) plus $100 \mathrm{mg} / \mathrm{m}^{2}$ cisplatin on days 1 and 22 . Three patients (4\%) died due to toxicity; 
Table V. Additional analysis: Comparison of accelerated fractionation plus chemotherapy (group A) and the different chemotherapy regimens included in the radiochemotherapy group (group B) with respect to locoregional control and overall survival. p-Values were obtained from logrank test.

\begin{tabular}{|c|c|c|c|c|}
\hline Endpoint & Type of chemotherapy & 1 Year $(\%)$ & 2 Years $(\%)$ & $p$-Value \\
\hline \multirow[t]{5}{*}{ Locoregional control } & Accelerated fractionation + chemotherapy $(n=10)$ & 89 & 53 & 0.39 \\
\hline & Cisplatin $30 \mathrm{mg} / \mathrm{m}^{2}$, every week $(\mathrm{n}=21)$ & 64 & 51 & \\
\hline & Cisplatin $100 \mathrm{mg} / \mathrm{m}^{2}$, every 3 weeks $(\mathrm{n}=17)$ & 76 & 76 & \\
\hline & Cisplatin $5 \times 20 \mathrm{mg} / \mathrm{m}^{2}$, every 4 weeks $(\mathrm{n}=24)$ & 83 & 83 & \\
\hline & Cisplatin $5 \times 20 \mathrm{mg} / \mathrm{m}^{2}+5$-FU, every 4 weeks $(\mathrm{n}=23)$ & 73 & 64 & \\
\hline \multirow[t]{5}{*}{ Overall survival } & Accelerated fractionation + chemotherapy $(n=10)$ & 50 & 40 & 0.015 \\
\hline & Cisplatin $30 \mathrm{mg} / \mathrm{m}^{2}$, every week $(\mathrm{n}=21)$ & 62 & 38 & \\
\hline & Cisplatin $100 \mathrm{mg} / \mathrm{m}^{2}$, every 3 weeks $(\mathrm{n}=17)$ & 88 & 80 & \\
\hline & Cisplatin $5 \times 20 \mathrm{mg} / \mathrm{m}^{2}$, every 4 weeks $(\mathrm{n}=24)$ & 92 & 87 & \\
\hline & Cisplatin $5 \times 20 \mathrm{mg} / \mathrm{m}^{2}+5$-FU, every 4 weeks $(\mathrm{n}=23)$ & 78 & 53 & \\
\hline
\end{tabular}

5-FU: 5-Fluorouracil. Significant $p$-values are given in bold.

additional 19 patients (25\%) experienced grade 4 and 49 patients (64\%) grade 3 acute toxicities. Despite the high toxicity, the authors rated this regimen as feasible. In another study, 40 consecutive patients received post-operative radiotherapy with 66 Gy over 5.5 weeks $(2.0$ Gy per fraction on 5 days per week plus $2.0 \mathrm{~Gy}$ as concomitant boost on day 5) plus $100 \mathrm{mg} / \mathrm{m}^{2}$ cisplatin on days 1, 22 and 43 (16). Grade 3 oral mucositis occurred in $25 \%$, grade 3 dermatitis in $13 \%$, grade $\geq 3$ anemia in $6 \%$, grade $\geq 3$ leucopenia in $13 \%$ and grade 3 nephrotoxicity in $3 \%$ of patients. Grade $\geq 2$ xerostomia and grade $\geq 2$ lymph edema occurred in $25 \%$ and $3 \%$ of patients, respectively. The authors described their regimen as "easily feasible with acceptable morbidity" (16). In 2010, a phase I study investigated the feasibility of HART with 70.6 Gy in 44 fractions over 6 weeks (30 Gy in 15 fractions over 3 weeks, followed by two 1.4 Gy fractions per day over 3 weeks) plus weekly cetuximab and cisplatin (17). Cisplatin-doses were escalated between 20 and $40 \mathrm{mg} / \mathrm{m}^{2}$. Grade $\geq 3$ oral mucositis occurred in $56 \%$, grade $\geq 3$ dermatitis in $38 \%$ and $\geq 3$ neutropenia in $25 \%$ of patients. These authors also considered their regimen feasible.

In addition to feasibility studies, randomized trials compared HA-RT or AF-CB plus chemotherapy to HA-RT or AF-CB alone. In 2000, Dobrowsky and Naude compared conventional fractionation (70 Gy/35 fractions) alone, HART (55.3 Gy in 33 fractions over 17 consecutive days) alone and HA-RT plus mitomycin C (20 mg/m² on day 5) (18). The addition of mitomycin $\mathrm{C}$ resulted in significantly improved LRC and OS compared to conventional radiotherapy and HART alone. Another randomized trial compared AF-CB (69.6 Gy in 30 fractions over 5.5 weeks) plus chemotherapy (two courses of $20 \mathrm{mg} / \mathrm{m}^{2}$ of carboplatin on days $1-5$ and 600 $\mathrm{mg} / \mathrm{m}^{2}$ of 5-FU on days 1-5) to AF-CB alone (19). Two-year LRC ( $51 \%$ versus $45 \%, p=0.14)$ and OS ( $48 \%$ versus $39 \%$, $p=0.11$ ) rates were non-significantly better after AF-CB plus chemotherapy. In patients with oropharyngeal cancer, 1-year local control $(60 \%$ versus $40 \%, p=0.009)$ and 1 -year OS (68\% versus $57 \%, p=0.047$ ) were significantly better in the AF-CB plus chemotherapy group (19).

In 2005, a randomized trial compared dose-escalated HART with $77.6 \mathrm{~Gy}$ in 52 fractions over 6 weeks $(8 \times 2.0 \mathrm{~Gy}$ over 1.5 weeks followed by two $1.4-$ Gy fractions per day over 4.5 weeks) to HA-RT with 70.6 Gy in 44 fractions over 6 weeks $(15 \times 2.0$ Gy over 3 weeks followed by two $1.4 \mathrm{~Gy}$ fractions per day over 4.5 weeks) plus mitomycin $\mathrm{C}$ (10 $\mathrm{mg} / \mathrm{m}^{2}$ on days 5 and 36$)$ and 5 -FU $\left(600 \mathrm{mg} / \mathrm{m}^{2}\right.$ on days 1 5) (20). HA-RT plus chemotherapy resulted in better LRC $(49.9 \%$ versus $37.4 \%, p=0.001)$ and OS $(28.6 \%$ versus $23.7 \%, p=0.023$ ) at 5 years.

These promising results led to two randomized trials comparing accelerated radiotherapy plus chemotherapy to conventional radiochemotherapy $(21,22)$. One trial compared AF-CB (70 Gy in 40 fractions over 6 weeks) plus carboplatin/5-FU to conventional fractionation (70 Gy in 35 fractions over 7 weeks) plus carboplatin/5-FU (21). AF-CB plus chemotherapy did not result in better progression-free survival than conventional radiochemotherapy (hazard ratio $=1.02,95 \% \mathrm{CI}=0.84-1.23, p=0.88)(21)$. In the other trial, AF-CB with 72 Gy in 42 fractions over 6 weeks plus two courses of $100 \mathrm{mg} / \mathrm{m}^{2}$ of cisplatin on day 1 was compared to conventional fractionation (70 Gy/35 fractions) plus three courses of the same cisplatin-dose (22). No significant differences were found for locoregional failure (hazard ratio $=1.08,95 \% \mathrm{CI}=0.84-1.38, p=0.78$ ) and $\mathrm{OS}$ (hazard ratio $=0.96,95 \% \mathrm{CI}=0.79-1.18, p=0.37$ ).

Other accelerated radiotherapy plus chemotherapy concepts have been developed and not yet compared to conventional radiochemotherapy. In the present study, 
outcomes of patients receiving one of three regimens of accelerated radiotherapy plus chemotherapy were compared to patients receiving conventional radiochemotherapy (2527). Groups were matched for several patient and tumor characteristics to reduce the risk of hidden selection biases. However, due to the retrospective nature of this study, this risk cannot be entirely excluded. In addition to the design, other limitations of the study exist including the small number of patients in group A, differences in treatment times and length of follow-up, and non-consideration of the human papilloma virus status; the latter was demonstrated to be a significant prognostic factor for OS in patients with HNSCC, particularly for those with oropharyngeal cancer (32-34).

According to the findings of the current study, accelerated radiotherapy plus chemotherapy did not result in better LRC and OS than conventional radiochemotherapy. Outcomes after accelerated radiotherapy plus chemotherapy appeared even worse when compared to conventional radiochemotherapy with $20 \mathrm{mg} / \mathrm{m}^{2}$ of cisplatin on days $1-5$ every 4 weeks or 100 $\mathrm{mg} / \mathrm{m}^{2}$ of cisplatin on day 1 every 3 weeks (Table $\mathrm{V}$ ). Moreover, accelerated radiotherapy plus chemotherapy was associated with significantly increased acute and late toxicities (Table IV). When considering the results of the two previous randomized trials and the present study, conventional radiochemotherapy should remain the standard treatment for unresectable HNSCC $(21,22)$. For conventional radiochemotherapy, $20 \mathrm{mg} / \mathrm{m}^{2}$ of cisplatin on days $1-5$ every 4 weeks appeared preferable, since this regimen was associated with the best LRC and OS rates at 2 years and was better tolerated than the other cisplatin-based regimens investigated in this study. These findings agree with previous studies suggesting that $20 \mathrm{mg} / \mathrm{m}^{2}$ of cisplatin on days $1-5$ every 4 weeks resulted in significantly better OS than weekly cisplatin $(\mathrm{RR}=1.17, p=0.011)$ and cisplatin plus 5-FU $(\mathrm{RR}=1.35, p=0.006)$ and in non-significantly better OS than $100 \mathrm{mg} / \mathrm{m}^{2}$ of cisplatin on day 1 every 3 weeks (80\% versus $68 \%$ at 3 years, $p=0.14)(35-37)$. Moreover, in the previous studies, $20 \mathrm{mg} / \mathrm{m}^{2}$ on days $1-5$ of cisplatin every 4 weeks was associated with fewer adverse events than cisplatin plus 5 -FU and $100 \mathrm{mg} / \mathrm{m}^{2}$ of cisplatin on day 1 every 3 weeks $(35,36)$.

In summary, given the limitations of this study, accelerated radiotherapy plus chemotherapy provided no significant benefit but increased toxicity compared to conventional radiochemotherapy. More favorable results were achieved with $20 \mathrm{mg} / \mathrm{m}^{2}$ of cisplatin on days $1-5$ every 4 weeks. Conventional radiochemotherapy should remain the standard treatment for unresectable locally advanced HNSCC. These findings need to be confirmed in randomized clinical trials.

\section{Conflicts of Interest}

The Authors report no conflicts of interest related to the present study.

\section{Authors' Contributions}

The study was designed by all Authors. Data were collected by C.A.N. and D.R. and analyzed by S.E.S. and D.R. The draft of the article was prepared by D.R. and S.E.S. and the final version approved by all Authors.

\section{References}

1 Mallick S, Benson R, Julka PK and Rath GK: Altered fractionation radiotherapy in head and neck squamous cell carcinoma. J Egypt Natl Canc Inst 28: 73-80, 2016. PMID: 26994645. DOI: $10.1016 /$ j.jnci.2016.02.004

2 Semrau R: The role of radiotherapy in the definitive and postoperative treatment of advanced head and neck cancer. Oncol Res Treat 40: 347-352, 2017. PMID: 28521321. DOI: 10.1159/000477128

3 Chow LQM: Head and neck cancer. N Engl J Med 382: 60-72, 2020. PMID: 31893516. DOI: 10.1056/NEJMra1715715

4 Bernier J, Cooper JS, Pajak TF, van Glabbeke M, Bourhis J, Forastiere A, Ozsahin EM, Jacobs JR, Jassem J, Ang KK and Lefèbvre JL: Defining risk levels in locally advanced head and neck cancers: a comparative analysis of concurrent postoperative radiation plus chemotherapy trials of the EORTC (\#22931) and RTOG (\# 9501). Head Neck 27: 843-850, 2005. PMID: 16161069. DOI: $10.1002 /$ hed.20279

5 Adelstein DJ, Lavertu P, Saxton JP, Secic M, Wood BG, Wanamaker JR, Eliachar I, Strome M and Larto MA: Mature results of a phase III randomized trial comparing concurrent chemoradiotherapy with radiation therapy alone in patients with stage III and IV squamous cell carcinoma of the head and neck. Cancer 88: 876-883, 2000. PMID: 10679658. DOI: 10.1002/(sici)1097-0142(20000215)88:4< 876::aid-cncr19>3.0.co;2-y

6 Denis F, Garaud P, Bardet E, Alfonsi M, Sire C, Germain T, Bergerot $\mathrm{P}$, Rhein B, Tortochaux J and Calais G: Final results of the 94-01 French Head and Neck Oncology and Radiotherapy Group randomized trial comparing radiotherapy alone with concomitant radiochemotherapy in advanced-stage oropharynx carcinoma. J Clin Oncol 22: 69-76, 2004. PMID: 14657228. DOI: $10.1200 / \mathrm{JCO} .2004 .08 .021$

7 Pignon JP, le Maître A, Maillard E and Bourhis J; MACH-NC Collaborative Group: Meta-analysis of chemotherapy in head and neck cancer (MACH-NC): An update on 93 randomised trials and 17,346 patients. Radiother Oncol 92: 4-14, 2009. PMID: 19446902. DOI: 10.1016/j.radonc.2009.04.014

8 Blanchard P, Baujat B, Holostenco V, Bourredjem A, Baey C, Bourhis J and Pignon JP; MACH-CH Collaborative group: Meta-analysis of chemotherapy in head and neck cancer (MACH-NC): A comprehensive analysis by tumour site. Radiother Oncol 100: 33-40, 2011. PMID: 21684027. DOI: 10.1016/j.radonc.2011.05.036

9 Cooper JS, Pajak TF, Forastiere AA, Jacobs J, Campbell BH, Saxman SB, Kish JA, Kim HE, Cmelak AJ, Rotman M, Machtay M, Ensley JF, Chao KS, Schultz CJ, Lee N and Fu KK; Radiation Therapy Oncology Group 9501/Intergroup: Postoperative concurrent radiotherapy and chemotherapy for high-risk squamouscell carcinoma of the head and neck. N Engl J Med 350: 19371944, 2004. PMID: 15128893. DOI: 10.1056/NEJMoa032646

10 Bernier J, Domenge C, Ozsahin M, Matuszewska K, Lefèbvre JL, Greiner RH, Giralt J, Maingon P, Rolland F, Bolla M, Cognetti F, 
Bourhis J, Kirkpatrick A and van Glabbeke M; European Organization for Research and Treatment of Cancer Trial 22931: Postoperative irradiation with or without concomitant chemotherapy for locally advanced head and neck cancer. N Engl J Med 350: 1945-1952, 2004. PMID: 15128894. DOI: 10.1056/NEJMoa032641

11 Rades D, Stoehr M, Kazic N, Hakim SG, Walz A, Schild SE and Dunst J: Locally advanced stage IV squamous cell carcinoma of the head and neck: Impact of pre-radiotherapy hemoglobin level and interruptions during radiotherapy. Int J Radiat Oncol Biol Phys 70: 1108-1114, 2008. PMID: 17905528. DOI: 10.1016/ j.ijrobp.2007.07.2380

12 Bourhis J, Overgaard J, Audry H, Ang KK, Saunders M, Bernier J, Horiot JC, Le Maître A, Pajak TF, Poulsen MG, O'Sullivan B, Dobrowsky W, Hliniak A, Skladowski K, Hay JH, Pinto LH, Fallai C, Fu KK, Sylvester R and Pignon JP; Meta-Analysis of Radiotherapy in Carcinomas of Head and Neck (MARCH) Collaborative Group: Hyperfractionated or accelerated radiotherapy in head and neck cancer: A meta-analysis. Lancet 368: 843-854, 2006. PMID: 16950362. DOI: 10.1016/S01406736(06)69121-6

13 Fu KK, Pajak TF, Trotti A, Jones CU, Spencer SA, Phillips TL, Garden AS, Ridge JA, Cooper JS and Ang KK: A Radiation Therapy Oncology Group (RTOG) phase III randomized study to compare hyperfractionation and two variants of accelerated fractionation to standard fractionation radiotherapy for head and neck squamous cell carcinomas: First report of RTOG 9003. Int J Radiat Oncol Biol Phys 48: 7-16, 2000. PMID: 10924966. DOI: 10.1016/s0360-3016(00)00663-5

14 Ang KK, Harris J, Garden AS, Trotti A, Jones CU, Carrascosa L, Cheng JD, Spencer SS, Forastiere A and Weber RS: Concomitant boost radiation plus concurrent cisplatin for advanced head and neck carcinomas: Radiation Therapy Oncology Group phase II trial 99-14. J Clin Oncol 23: 30083015, 2005. PMID: 15860857. DOI: 10.1200/JCO.2005.12.060

15 Garden AS, Harris J, Trotti A, Jones CU, Carrascosa L, Cheng JD, Spencer SS, Forastiere A, Weber RS and Ang KK. Longterm results of concomitant boost radiation plus concurrent cisplatin for advanced head and neck carcinomas: A phase II trial of the radiation therapy oncology group (RTOG 99-14). Int J Radiat Oncol Biol Phys 71: 1351-1355, 2008. PMID: 18640496. DOI: $10.1016 /$ j.jjrobp.2008.04.006

16 Pehlivan B, Luthi F, Matzinger O, Betz M, Dragusanu D, Bulling S, Bron L, Pasche P, Seelentag W, Mirimanoff RO, Zouhair A and Ozsahin M: Feasibility and efficacy of accelerated weekly concomitant boost postoperative radiation therapy combined with concomitant chemotherapy in patients with locally advanced head and neck cancer. Ann Surg Oncol 16: 1337-1343, 2009. PMID: 19280263. DOI: 10.1245/s10434009-0426-4

17 Kuhnt T, Sandner A, Wendt T, Engenhart-Cabillic R, Lammering G, Flentje M, Grabenbauer G, Schreiber A, Pirnasch A and Dunst J: Phase I trial of dose-escalated cisplatin with concomitant cetuximab and hyperfractionated-accelerated radiotherapy in locally advanced squamous cell carcinoma of the head and neck. Ann Oncol 21: 2284-2289, 2010. PMID: 20427347. DOI: $10.1093 /$ annonc/mdq216

18 Dobrowsky W and Naudé J: Continuous hyperfractionated accelerated radiotherapy with/without mitomycin $\mathrm{C}$ in head and neck cancers. Radiother Oncol 57: 119-124, 2000. PMID: 11054514. DOI: $10.1016 / \mathrm{s} 0167-8140(00) 00233-4$
19 Staar S, Rudat V, Stuetzer H, Dietz A, Volling P, Schroeder M, Flentje M, Eckel HE and Mueller RP: Intensified hyperfractionated accelerated radiotherapy limits the additional benefit of simultaneous chemotherapy-results of a multicentric randomized German trial in advanced head-and-neck cancer. Int J Radiat Oncol Biol Phys 50: 1161-1171, 2001. PMID: 11483325. DOI: 10.1016/s0360-3016(01)01544-9

20 Budach V, Stuschke M, Budach W, Baumann M, Geismar D, Grabenbauer G, Lammert I, Jahnke K, Stueben G, Herrmann T, Bamberg M, Wust P, Hinkelbein W and Wernecke KD: Hyperfractionated accelerated chemoradiation with concurrent fluorouracil-mitomycin is more effective than dose-escalated hyperfractionated accelerated radiation therapy alone in locally advanced head and neck cancer: Final results of the radiotherapy cooperative clinical trials group of the German Cancer Society 95-06 prospective randomized trial. J Clin Oncol 23: 1125-1135, 2005. PMID: 15718308. DOI: 10.1200/JCO.2005.07.010

21 Bourhis J, Sire C, Graff P, Grégoire V, Maingon P, Calais G, Gery B, Martin L, Alfonsi M, Desprez P, Pignon T, Bardet E, Rives M, Geoffrois L, Daly-Schveitzer N, Sen S, Tuchais C, Dupuis O, Guerif S, Lapeyre M, Favrel V, Hamoir M, Lusinchi A, Temam S, Pinna A, Tao YG, Blanchard P and Aupérin A: Concomitant chemoradiotherapy versus acceleration of radiotherapy with or without concomitant chemotherapy in locally advanced head and neck carcinoma (GORTEC 99-02): An open-label phase 3 randomised trial. Lancet Oncol 13: 145153, 2012. PMID: 22261362. DOI: 10.1016/S1470-2045(11) 70346-1

22 Nguyen-Tan PF, Zhang Q, Ang KK, Weber RS, Rosenthal DI, Soulieres D, Kim H, Silverman C, Raben A, Galloway TJ, Fortin A, Gore E, Westra WH, Chung CH, Jordan RC, Gillison ML, List M and Le QT: Randomized phase III trial to test accelerated versus standard fractionation in combination with concurrent cisplatin for head and neck carcinomas in the Radiation Therapy Oncology Group 0129 trial: Long-term report of efficacy and toxicity. J Clin Oncol 32: 3858-3866, 2014. PMID: 25366680. DOI: $10.1200 / J C O .2014 .55 .3925$

23 Edge SB, Byrd DR, Compton CC, Fritz AG, Greene FL and Trotti A (eds.): AJCC Cancer Staging Manual (Seventh Edition). New York, NY: Springer; 2010.

24 Amin MB, Edge S, Greene F, Byrd DR, Brookland RK, Washington MK, Gershenwald JE, Compton CC, Hess KR, Sullivan DC, Jessup JM, Brierley JD, Gaspar LE, Schilsky RL, Balch CM, Winchester DP, Asare EA, Madera M, Gress DM and Meyer LR (eds.): AJCC Cancer Staging Manual (Eighth Edition). New York, NY: Springer; 2017.

25 Kuhnt T, Schreiber A, Pirnasch A, Hautmann MG, Hass P, Sieker FP, Engenhart-Cabillic R, Richter M, Dellas K and Dunst $\mathrm{J}$ : Hyperfractionated accelerated radiation therapy plus cetuximab plus cisplatin chemotherapy in locally advanced inoperable squamous cell carcinoma of the head and neck: Final 5-year results of a phase II study. Strahlenther Onkol 193: 733741, 2017. PMID: 28500491. DOI: 10.1007/s00066-017-1145-6

26 Dietz A, Wichmann G, Kuhnt T, Pfreundner L, Hagen R, Scheich M, Kölbl O, Hautmann MG, Strutz J, Schreiber F, Bockmühl U, Schilling V, Feyer P, de Wit M, Maschmeyer G, Jungehülsing M, Schroeder U, Wollenberg B, Sittel C, Münter M, Lenarz T, Klussmann JP, Guntinas-Lichius O, Rudack C, Eich HT, Foerg T, Preyer S, Westhofen M, Welkoborsky HJ, Esser D, Thurnher D, Remmert S, Sudhoff H, Görner M, Bünzel 
J, Budach V, Held S, Knödler M, Lordick F, Wiegand S, Vogel $\mathrm{K}$, Boehm A, Flentje M and Keilholz U: Induction chemotherapy (IC) followed by radiotherapy (RT) versus cetuximab plus IC and RT in advanced laryngeal/hypopharyngeal cancer resectable only by total laryngectomy-final results of the larynx organ preservation trial DeLOS-II. Ann Oncol 29: 2105-2114, 2018. PMID: 30412221. DOI: 10.1093/annonc/mdy332

27 Fietkau R, Hecht M, Hofner B, Lubgan D, Iro H, Gefeller O, Rödel C, Hautmann MG, Kölbl O, Salay A, Rübe C, Melchior P, Breinl P, Krings W, Gripp S, Wollenberg B, Keerl R, Schreck U, Siekmeyer B, Grabenbauer GG and Balermpas P; PacCisStudy Group: Randomized phase-III-trial of concurrent chemoradiation for locally advanced head and neck cancer comparing dose reduced radiotherapy with paclitaxel/cisplatin to standard radiotherapy with fluorouracil/cisplatin: The PacCistrial. Radiother Oncol 144: 209-217, 2020. PMID: 32044419. DOI: $10.1016 /$ j.radonc.2020.01.016

28 Mikoshiba T, Ozawa H, Saito S, Ikari Y, Nakahara N, Ito F, Watanabe Y, Sekimizu M, Imanishi Y and Ogawa K: Usefulness of hematological inflammatory markers in predicting severe side-effects from induction chemotherapy in head and neck cancer patients. Anticancer Res 39: 3059-3065, 2019. PMID: 31177149. DOI: 10.21873 /anticanres. 13440

29 Bonner JA, Harari PM, Giralt J, Cohen RB, Jones CU, Sur RK, Raben D, Baselga J, Spencer SA, Zhu J, Youssoufian H, Rowinsky EK and Ang KK: Radiotherapy plus cetuximab for locoregionally advanced head and neck cancer: 5-Year survival data from a phase 3 randomised trial, and relation between cetuximab-induced rash and survival. Lancet Oncol 11: 21-28, 2010. PMID: 19897418. DOI: 10.1016/S1470-2045(09)70311-0

30 Guan J, Li Q, Zhang Y, Xiao N, Chen M, Zhang Y, Li L and Chen L: A meta-analysis comparing cisplatin-based to carboplatin-based chemotherapy in moderate to advanced squamous cell carcinoma of head and neck (SCCHN). Oncotarget 7: 7110-7119, 2016. PMID: 26755647. DOI: 10.18632 /oncotarget.6858

31 Beitler JJ, Zhang Q, Fu KK, Trotti A, Spencer SA, Jones CU, Garden AS, Shenouda G, Harris J and Ang KK: Final results of local-regional control and late toxicity of RTOG 9003: A randomized trial of altered fractionation radiation for locally advanced head and neck cancer. Int J Radiat Oncol Biol Phys 89: 13-20, 2014. PMID: 24613816. DOI: 10.1016/j.ijrobp.2013.12.027
32 Rades D, Seibold ND, Hoffmann A, Gebhard MP, Noack F, Thorns C and Schild SE: Impact of the HPV-positivity definition on the prognostic value of HPV status in patients with locally advanced squamous cell carcinoma of the head and neck. Strahlenther Onkol 189: 856-860, 2013. PMID: 23868550. DOI: 10.1007/s00066-013-0377-3

33 Wookey VB, Appiah AK, Kallam A, Ernani V, Smith LM and Ganti AK: HPV status and survival in non-oropharyngeal squamous cell carcinoma of the head and neck. Anticancer Res 39: 1907-1914, 2019. PMID: 30952732. DOI: 10.21873/anticanres.13299

34 De Jesus Oliveira Kato V, De Abreu MC, De Brito Kato AM, De Souza LL, Pontes FSC, De Castro Sant'anna C, GonÇalves A Jr., Pontes HAR, Khayat AS and Burbano RMR: Significance of p16 INK4A expression and PTEN loss of heterozygosity in human papilloma virus-related oral squamous cell carcinoma. Anticancer Res 40: 6355-6366, 2020. PMID: 33109573. DOI: 10.21873/anticanres. 14656

35 Rades D, Seidl D, Janssen S, Strojan P, Karner K, Bajrovic A, Hakim SG, Wollenberg B and Schild SE: Comparing two lowerdose cisplatin programs for radiochemotherapy of locally advanced head-and-neck cancers. Eur Arch Otorhinolaryngol 274: 1021-1027, 2017. PMID: 27687678. DOI: 10.1007/s00405016-4326-5

36 Rades D, Seidl D, Janssen S, Bajrovic A, Hakim SG, Wollenberg B, Karner K, Strojan P and Schild SE: Chemoradiation of locally advanced squamous cell carcinoma of the head-and-neck (LASCCHN): Is $20 \mathrm{mg} / \mathrm{m}(2)$ cisplatin on five days every four weeks an alternative to $100 \mathrm{mg} / \mathrm{m}(2)$ cisplatin every three weeks? Oral Oncol 59: 67-72, 2016. PMID: 27424184. DOI: 10.1016/j.oraloncology.2016.06.004

37 Rades D, Seidl D, Janssen S, Bajrovic A, Hakim SG, Wollenberg $\mathrm{B}$ and Schild SE: Do we need 5-FU in addition to cisplatin for chemoradiation of locally advanced head-and-neck cancer? Oral Oncol 57: 40-45, 2016. PMID: 27208843. DOI: 10.1016/ j.oraloncology.2016.04.003

Received December 9, 2020

Revised December 22, 2020

Accepted December 23, 2020 